him of most of life's illusions, and yet left him determined to confront and probe its fundamental questions, which he did regularly with friends, colleagues, and students.

Ken's family and colleagues encourage those wishing to make a donation in his name to consider doing so to a Marquette University department of political science lounge in which many of his books will be housed and students and faculty will be able to meet.

Michael Fleet

James Rhodes

Marquette University

\section{Martin L. Faust}

Martin Faust, Emeritus Professor at the University of MissouriColumbia died on August 13, 1993, at the age of 95 .

Martin was a native of Pennsylvania. After service in the Army infantry in World War 1 , he took his A.B. (1919) and A.M. (1920) at Gettysburg College, where he was a Phi Beta Kappa, and a member of Pi Sigma Alpha. He studied at the University of Pennsylvania for a year, then received a Ph.D. from University of Chicago in 1924, where he was a Political Science Fellow while Leonard White was developing the study of public administration, and Charles Merriam was stimulating students to study state and local government, especially Chicago, in an effort to improve it. Martin continued throughout his life this commitment to good government, especially government with efficient and effective administration.

Martin was an instructor at Gettysburg Academy while working on his M.A. degree, then an instructor at Western Reserve University for a year after studying at Pennsylvania. After completing his Ph.D. at Chicago, he taught for five years at the University of Pittsburgh, then accepted an associate professorship at the University of Missouri in 1929. He also taught summers at Syracuse University, San Jose State College, and the University of Illinois.

He taught at Missouri for 38 years, serving also as chair of the department 1940-49, and 1953-58, and as acting director of the $\mathrm{Bu}$ reau of Government Research in 1959-61. He taught particularly the public administration classes. He was well informed, well organized, conscientious, and careful. After his retirement, the Martin L. Faust Lecture Series on Public Administration was established in his honor.

Martin maintained an active research agenda throughout his career, devoting much of his research to the effort to improve the quality of government. Martin was heavily involved in preparations for the Missouri Constitutional Convention of 1943-44. He prepared an organization manual, and manuals on the legislative article, the executive article, the amending procedure, and the initiative and referendum. After the constitution was adopted, Martin published an evaluation of the constitution after five years, an analysis of the constitution and administrative structure after 19 years, and a history of the adoption of the constitution. Martin also published articles on municipal government, public finance, state government and Missouri government in various journals and books, including The Annals, the Municipal Yearbook, the National Municipal Review, the American Political Science Review, and the Washington University Law Quarterly.

He served for many years as the University's consultant on state and local government matters. $\mathrm{He}$ was director of studies for the Missouri Constitutional Convention, 1943-44, a staff member of the Legislative Research Committee, 1945, a consultant for the State Reorganization Commission of 1955, and a consultant for the Committee on the Executive Branch of the Michigan Constitutional Convention, 1961. He was a member of the Columbia Charter Commission, 194849 , and a member of the city Planning and Zoning Commission and the city Personnel Board. In 1962, the university developed a Local Government Extension program which assumed much of the consulting and public service activities that Martin had conducted over the years.

Martin Faust was a member of the executive council of the American Political Science Association in 1939-41, president of the Missouri Political Science Association, 1963, a member of the Joint Committee, U.S. Department of Agriculture and Land Grant College on Training for Government Service, and a member of the Committee on State Government of the National Municipal League.

Martin married Ann Baker, who preceded him in death in 1974 . She worked many years on issues of public health and city government. She worked to secure city-wide refuse pickup and to reduce water pollution in Columbia through use of biodegradable products. He married Margaret Bolstad in 1975 and she survives. Surviving also is a son, David, of Raytown, a stepson and two stepdaughters, two grandsons and one great-grandchild.

David A. Leuthold
Dean L. Yarwood
University of Missouri-Columbia

\section{Kenneth E. Hofiman}

Kenneth Edward Hoffman, 76, died Tuesday, December 14, 1993 in Morehead, Kentucky. He was a member of the Church of Jesus Christ of Latter Day Saints and was an associate professor of political science of Morehead State University, where he had taught for over 20 years. Also, prior to teaching government, he was elected as a Selectman, Town of Kirby, Vermont, and served in the Vermont legislature. $\mathrm{He}$ is survived by his wife, Janice Inlay Hoffman, two sons and one daughter.

\section{Lindsey Beck Morehead State University}

\section{Albert Lepawsky}

Albert Lepawsky was born in Chicago, Illinois, on February 16, 1908 , the son of Russian Jewish immigrants. He died in Berkeley, California, after a long and debilitating illness in June 1992 at age 84. 